\title{
Ertugliflozin (Steglatro): New Drug in the Family
}

\author{
Natasha N Colvin \\ Department of Pharmacy, South University School of Pharmacy, USA
}

Submission: January 19, 2017; Published: January 26, 2018

*Corresponding author: Natasha N Colvin, Department of Pharmacy, South University School of Pharmacy, 10 Science Court, Columbia, SC, 29203, USA, Tel: 8032095725; Fax: 8039354564; Email: ncolvin@southuniversity.edu

Abstract

Ertugliflozin, a sodium glucose co-transporter inhibitor, was approved by the FDA on December 22, 2017 for patients with type 2 diabetes. For patients requiring multiple medications to help manage their diabetes and lower their A1C, ertugliflozin may be an appropriate option. This article discusses appropriate dosing, use, and monitoring.

Keywords: Diabetes; Glucose control; Management; Ertugliflozin; Steglatro; Sodium glucose co-transporter inhibitor

Abbreviations: T2DM: Type 2 Diabetes; HbA1c: Glycosylated Hemoglobin; SGLT2: Sodium Glucose Co-Transporter 2, FDA: Food and Drug Administration; (eGFR): estimated Glomerular Filtration Rate

\section{Introduction}

Ranked as a leading cause of death in the United States, diabetes affects approximately 30 million Americans of which 90-95\% has type 2 diabetes (T2DM) and one-third of those individuals are not at their glycosylated hemoglobin (HbA1c) goal [1]. The American Diabetes Association (ADA) annually publishes the global standards of medical care in diabetes to reflect upon the latest advances and improve care for people living with diabetes [2]. With many new drugs coming to market, it is important that prescribers choose the appropriate therapy to suit the patient's needs while also helping them reaches their glycemic goals.

\section{SGLT-2 Inhibitors}

Sodium-glucose co-transporter 2 (SGLT2) is a human protein that facilitates glucose reabsorption in the proximal tubule in the kidneys [2]. A relatively new class of agents, SGLT2 inhibitors work by blocking glucose reabsorption in the proximal renal tubule by inhibiting SGLT2 [2]. Similar to most diabetes-treating medications, these agents are taken orally once daily [3]. This class of agents have the potential to provide modest weight loss and blood pressure reduction in patients with type 2 diabetes (T2DM) [2]. SGLT2 inhibitors may have glycemic benefits in patients with T2DM on insulin therapy and reduce the amount of insulin needed [2] Table 1 displays SGLT2 inhibitors that are currently Food and Drug Administration (FDA) approved in the United States.

\section{Ertugliflozin}

Ertugliflozin was approved by the FDA on December 22, 2017 as an adjunct to diet and exercise to improve glycemic control in adults with T2DM [4]. It is available in $5 \mathrm{mg}$ and $15 \mathrm{mg}$ tablets which should be used according to the dosing schedule in Table 1 [4]. Ertugliflozin is currently available at a wholesale acquisition cost of $\$ 8.94$ per day which does not include discounts [4]. In the VERTIS SITA2 trial, the $5 \mathrm{mg}$ and $15 \mathrm{mg}$ dose of ertugliflozin resulted in significant $\mathrm{HbA1c}$, fasting plasma glucose, body weight and systolic blood pressure reductions when used in combination with metformin plus sitagliptin [4] HbA1c reductions were $0.7 \%$ with the $5 \mathrm{mg}$ dose and $0.8 \%$ with the $15 \mathrm{mg}$ dose compared to $0.2 \%$ with placebo [4]. Fasting plasma glucose reductions were $25.7 \mathrm{mg} / \mathrm{dL}$ with the $5 \mathrm{mg}$ dose and $32.1 \mathrm{mg} / \mathrm{dL}$ with the $15 \mathrm{mg}$ dose compared to $6.5 \mathrm{mg} / \mathrm{dL}$ with placebo [4]. Body weight reductions were 6.6 pounds with the $5 \mathrm{mg}$ dose and 6.2 pounds with the $15 \mathrm{mg}$ dose compared to 2.2 pounds with placebo [4]. Systolic blood pressure reductions were $3.8 \mathrm{mmHg}$ with the $5 \mathrm{mg}$ dose and $4.5 \mathrm{mmHg}$ with the $15 \mathrm{mg}$ dose compared to $0.2 \mathrm{mmHg}$ with placebo [4] 
Table 1: FDA Approved SGLT2 Inhibitors in the United States [2,3].

\begin{tabular}{|c|c|c|}
\hline Drug & Dosing & Renal Dosing \\
\hline \multirow{3}{*}{ Canagliflozin (Invokana) } & $100 \mathrm{mg}$ once daily before first meal of the day & No adjustment if eGFR $\geq 60 \mathrm{~mL} / \mathrm{min} / 1.73 \mathrm{~m} 2$ \\
\hline & \multirow{2}{*}{ May increase to $300 \mathrm{mg}$ once daily as tolerated } & $100 \mathrm{mg}$ daily if eGFR $45-59 \mathrm{~mL} / \mathrm{min} / 1.73 \mathrm{~m} 2$ \\
\hline & & Avoid use if eGFR $<45 \mathrm{~mL} / \mathrm{min} / 1.73 \mathrm{~m} 2$ \\
\hline \multirow{3}{*}{ Dapagliflozin (Farxiga) } & $5 \mathrm{mg}$ once daily, in the morning & No adjustment if eGFR $\geq 60 \mathrm{~mL} / \mathrm{min} / 1.73 \mathrm{~m} 2$ \\
\hline & \multirow[t]{2}{*}{ May increase to $10 \mathrm{mg}$ once daily as tolerated } & $\begin{array}{l}\text { Not recommended if eGFR } 30-60 \mathrm{~mL} / \\
\mathrm{min} / 1.73 \mathrm{~m} 2\end{array}$ \\
\hline & & Avoid use if eGFR $<30 \mathrm{~mL} / \mathrm{min} / 1.73 \mathrm{~m} 2$ \\
\hline \multirow{3}{*}{ Empagliflozin (Jardiance) } & $10 \mathrm{mg}$ once daily, in the morning & No adjustment if eGFR $\geq 45 \mathrm{~mL} / \mathrm{min} / 1.73 \mathrm{~m} 2$ \\
\hline & \multirow[t]{2}{*}{ May increase to $25 \mathrm{mg}$ once daily as tolerated } & $\begin{array}{l}\text { Not recommended if eGFR } 30-45 \mathrm{~mL} / \\
\min / 1.73 \mathrm{~m} 2\end{array}$ \\
\hline & & Avoid use if eGFR $<30 \mathrm{~mL} / \mathrm{min} / 1.73 \mathrm{~m} 2$ \\
\hline \multirow{3}{*}{ Ertugliflozin (Steglatro) } & 5mg once daily, in the morning & No adjustment if eGFR $\geq 60 \mathrm{~mL} / \mathrm{min} / 1.73 \mathrm{~m} 2$ \\
\hline & \multirow[t]{2}{*}{ May increase to $15 \mathrm{mg}$ once daily as tolerated } & $\begin{array}{l}\text { Not recommended if eGFR } 30-60 \mathrm{~mL} / \\
\mathrm{min} / 1.73 \mathrm{~m} 2\end{array}$ \\
\hline & & Avoid use if eGFR< $30 \mathrm{~mL} / \mathrm{min} / 1.73 \mathrm{~m} 2$ \\
\hline
\end{tabular}

\section{Adverse Reactions}

The most common side effects associated with ertugliflozin are female genital mycotic infections which had an observed incidence of $\geq 5 \%$ [5]. Other warnings and precautions that are associated with ertugliflozin include: hypotension, diabetic ketoacidosis, intravascular volume contraction/depletion, acute kidney injury/renal impairment, lower limb amputation, hypoglycemia, and increase in low-density lipoprotein cholesterol (LDL) [5]. Renal function should be assessed before initiation and periodically with use of ertugliflozin [5]. Ertugliflozin should be renally adjusted according to the dosing schedule in Table 1.

\section{Conclusion}

This new once-daily SGLT2 inhibitor, ertugliflozin, will add to the competition of the class. However, it could serve as an

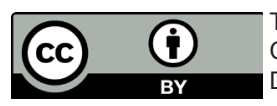

This work is licensed under Creative Commons Attribution 4.0 Licens

DOI: 10.19080/JOJCS.2018.05.555674 additional option for better glycemic control amongst individuals with T2DM while also reducing body weight and blood pressure which could benefit the individual's overall health.

\section{References}

1. (2017) Statistics about diabetes. American Diabetes Association, USA.

2. (2018) Standards of medical care in diabetes-2018. American Diabetes Association. Diabetes Care.

3. Lexi-Drugs. Lexi comp. Wolters Kluwer Health, Inc. Hudson $\mathrm{OH}$.

4. (2017) FDA approves SGLT2 inhibitors Steglatro ${ }^{\mathrm{TM}}$ (ertugliflozin) and fixed-dose combination Steglujan ${ }^{\text {TM }}$ (ertugliflozin and sitagliptin) for adults with type 2 diabetes. Pfizer.

5. (2017) Steglatro (ertugliflozin) [package insert]. Merck Sharp \& Dohme Corp., Whitehouse Station.

\begin{tabular}{l} 
Your next submission with Juniper Publishers \\
will reach you the below assets \\
- Quality Editorial service \\
- Swift Peer Review \\
- Reprints availability \\
- E-prints Service \\
- Manuscript Podcast for convenient understanding \\
- Global attainment for your research \\
- Manuscript accessibility in different formats \\
( Pdf, E-pub, Full Text, Audio) \\
- Unceasing customer service \\
Track the below URL for one-step submission \\
https://juniperpublishers.com/online-submission.php \\
\hline
\end{tabular}

